\title{
EVOLUTION OF DROSOPHILA ON THE NEWER HAWAIIAN VOLCANOES
}

\author{
HAMPTON L. CARSON \\ Department of Genetics, University of Hawaii, Honolulu, Hawaii 96822, U.S.A.
}

Received 15.x.81

\section{SUMMARY}

The 20-year odyssey taken by the Hawaiian Drosophila project has recently become focussed on a selected microcosm: this consists of the Island of Hawaii ("the Big Island") and one of its endemic species, Drosophila silvestris. Both the island and the species are considerably less than one million years old. Along with a morphologically distinct, but partially sympatric, close relative, $D$. heteroneura, silvestris inhabits moderate-altitude rainforests. They are the only members of the planitibia subgroup that occur on this island. The distribution of these species is discontinuous due to the dissection of the forests by recent lava flows and to the irregular distribution of their main host plants. Although allozyme heterozygosity within both species is considerable, local populations of both species show high similarity coefficients. The two species are, furthermore, virtually indistinguishable electrophoretically; nevertheless, significant differences in single-copy DNA have been demonstrated. Within silvestris, five inversion polymorphisms are widespread; six others have more restricted distributions. Populations in some of the geologically newer areas are the most polymorphic, both chromosomally and morphologically. Altitudinal clines of gene arrangement frequency are clear in areas on both sides of the island. The same inversions are involved in these clines on the two sides of the island. Males of silvestris from populations from the north and east side of the island ("Hilo-side") display a novel morphological secondary sexual character. This is absent not only from south and west ("Kona-side") silvestris but also from heteroneura and from the three closely related species endemic to older adjacent islands. In view of the phylogenetic novelty of this evolutionary development, Hilo-side silvestris is judged to be derived from Kona-side rather than vice versa. The character in question involves the addition of about 25 large cilia to the dorsal surface of the tibia of the male. This portion of the leg is used in a very specific fashion to stimulate the female's abdomen during the courtship ritual. Studies of sexual behaviour of individuals drawn from various natural and laboratory populations of silvestris and its relatives have been carried out. Hybrid sterility and/or inviability is lacking in crosses both within and between populations of heteroneura and silvestris. An interesting regularity has been widely observed: there is a positive correlation between the phylogenetic age of a population and the degree of discrimination by the female sex in mating. When this principle is applied to silvestris populations, the Kona-side populations of Hualalai volcano are judged to be the oldest in the species. As expected, Hilo-side populations with the novel bristle character appear to be newlyderived. The behavioural data further suggest that the novel bristle character arose in Kohala mountain populations from Hualalai ancestors and spread south and east from there toward the currently active volcanic areas where further behavioural, morphological and chromosomal changes are continuing. Preliminary evidence indicates that the behavioural attributes, as well as the bristle character, have a polygenic basis, held in balance by stabilizing sexual selection. This secondary sexual differentiation appears to serve as a model, at the 
microevolutionary level, of the kind of genetic change which has characterized the evolution of much of the Hawaiian Drosophilidae. Specifically, new behavioural patterns appear to have become established through novel but delicate gene tic coadaptation of male and female behaviour. The process appears to be driven by sexual selection, with shifts of balance being abetted by the founder effect. Adaptations to the ambient environment are pronounced as these flies evolve, yet they appear to follow speciation rather than initiate it.

\section{INTRODUCTION}

THE high Hawaiian Islands are all geologically young, having been formed since the middle Pliocene, by volcanic action in an extremely isolated area in the central Pacific Ocean (fig. 1). Despite the recent origin of these oceanic islands, their endemic terrestrial biota not only shows exuberant adaptations and species formation but also give evidence of having evolved in situ from a few waif ancestors which arrived by long-distance dispersal. Accordingly, Hawaiian ecosystems form superb natural laboratories in space and time for the study of the activities of evolutionary processes.

By a great stroke of luck, it has turned out that the genus Drosophila has been extraordinarily developed on the six main islands at the newest end of the archipelago. Since this favourable research opportunity was first recognized about twenty years ago, intensive basic work has been carried out with an eye to developing a major case study of the historical element in biology.

D. E. Hardy (University of Hawaii) and W. S. Stone (University of Texas), who conceived the project, encouraged a multidisciplinary approach. As a result, the broad outlines of the systematics of the family Drosophilidae as represented in the islands, were supplemented by studies of geographical distribution, ecology, biochemistry, life history, development, behaviour and population biology of these insects. In particular, the unique properties of Drosophila for genetic studies in the laboratory have been extensively exploited. These have permitted the construction of a series of realistic phylogenetic schemes based on chromosomal and molecular comparisons superimposed on a relatively simple recent geological history. Although a number of general accounts of this broader phylogenetic work have been published (e.g., Carson et al., 1970; Carson and Kaneshiro, 1976; Carson and Yoon, 1982), the ecological and population genetics of selected species has not been specifically reviewed. Accordingly, the present review intends to emphasize such work, most particularly that which has been carried out on Drosophila silvestris (Perkins). This species is endemic to the five newest volcanoes at the east end of the archipelago. These make up the present island of Hawaii ("the Big Island"), which is the newest and by far the highest and largest island in the archipelago.

In order to interpret the data on silvestris, it is necessary to consider its close relatives found on the volcanoes of the Maui-Molokai-Lanai complex of islands located immediately to the northwest of the Big Island (fig. 1, inset at lower right-hand corner).

The suitability of concentrating attention on the southeast volcanoes of the archipelago becomes even clearer when one considers the leading theory of the mode of origin of the islands. Evidence from erosional patterns, potassium-argon conversion and magnetic declination data indicate that the volcanoes are increasingly younger as one proceeds stepwise 


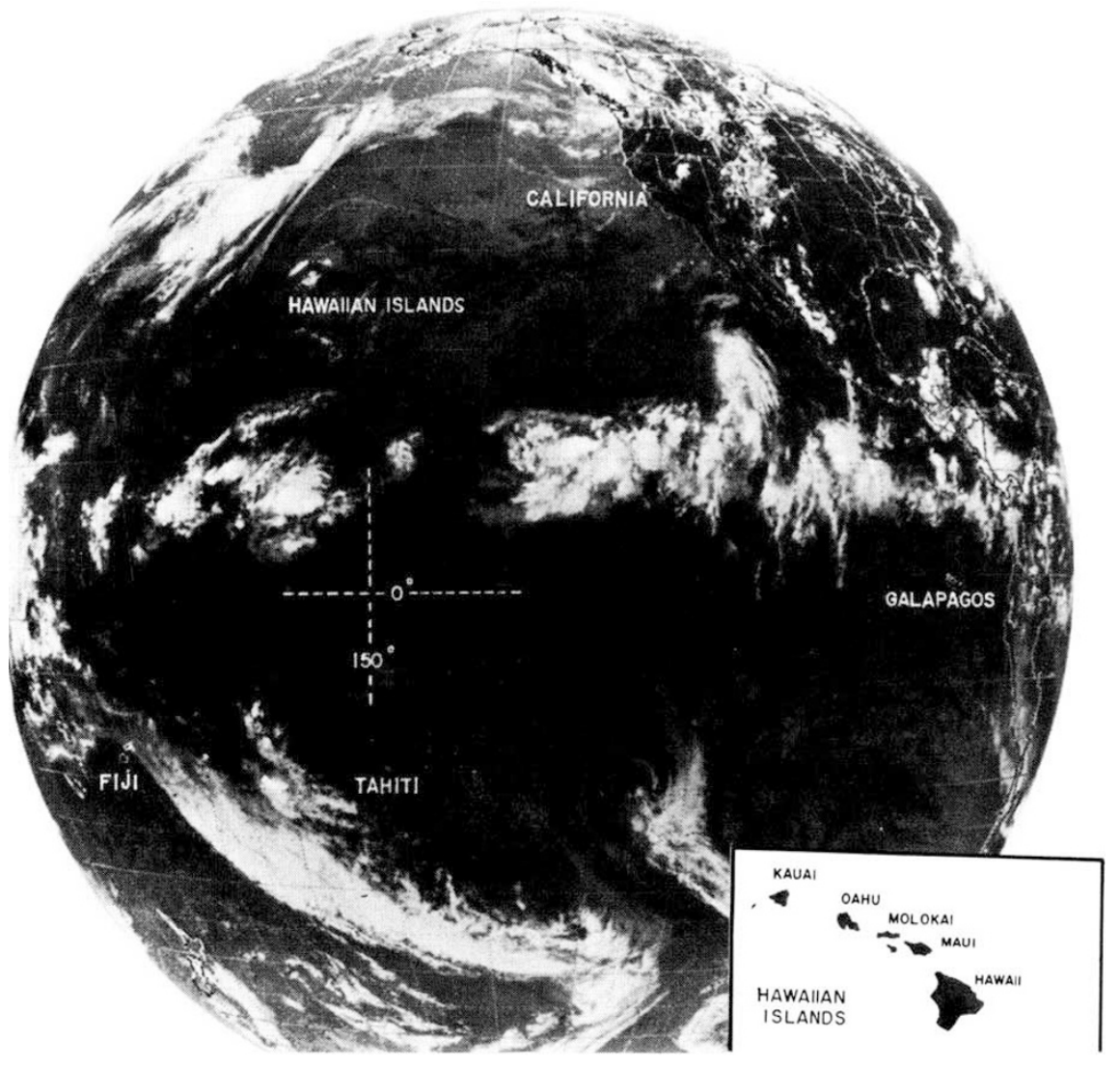

FIG. 1.-Satellite photograph of the eastern portion of the Pacific Ocean. The major high Hawaiian islands are shown enlarged at the lower right-hand corner. Photograph courtesy of the National Environment Satellite Service, U.S.A. 
from the northwest towards the southeast end of the archipelago. Indeed, the study of plate tectonics has resulted in the extraordinary and yet realistic theory that each Hawaiian volcano has been successively formed over a single upwelling plume of the earth's mantle. This plume, furthermore, is believed to have occupied a fixed position under the vast Pacific tectonic plate for at least five or six million years. Thus, the very hot lavas have apparently periodically perforated the plate, resulting in the formation of a volcano that surfaces above the Pacific Ocean. The plate is known to be moving northwestward at the rate of about $9 \mathrm{~cm}$ per year; it thus provides a moving target for the fixed "hot spot". Calculations show that approximately 5.6 million years ago, the rather extensively eroded volcano comprising the island of Kauai was formed over the hot spot. The island, affixed to the plate, has apparently moved in a northwesterly direction as the more recent volcanoes were subsequently formed in a similar manner.

At the present time, surface volcanic activity is confined to the extreme southeastern end of the archipelago, specifically at the vast, barely eroded shield volcano of Mauna Loa and its newer satellite, Kilauea Volcano. In this area one may now observe in an active state the kind of dynamics which have built the archipelago. It is on these newest volcanoes that both historic and pre-historic rift flows have coursed down the slopes to the sea. Not only does the island increase in size in this manner but the flows also have drastic biological effects, destroying large areas of older forests in a haphazard fashion. Frequently, certain forested areas escape destruction and remain as "kipukas", that is, islands of forest surrounded by desolate new lavas which nonetheless are destined to be recolonized in the continuing cycle of the growth of the mountain and its ecosystems.

Kohala Volcano, at the northwest end of the Big Island, has the oldest lava flows of any of the five volcanoes on the island; its maximum age is approximately 700,000 years (for location, see fig. 2). As expected, Kohala shows the most pronounced erosional pattern on the island. Here, the heavy rainfall brought by the prevailing northeast trade winds have eroded large amphitheatre-like valleys characteristic of the older volcanoes of the Maui complex, such as West Maui and the somewhat older volcano which makes up the east end of Molokai.

These powerful forces of erosion set in as vulcanism declines. From about $1500 \mathrm{~m}$ altitude to sea level, the persistent moisture-laden trade winds nurture the development of rain and cloud forests on the northeast slopes. Most of the leeward areas are xeric, receiving moisture only from the storms which occasionally develop from the south when the trades became temporarily diminished.

The biota of the islands, prior to modern introductions, was composed of the descendents of waifs which arrived by long-distance dispersal mostly from the east, west and south. The flora is a curious mixture. Some early herbaceous immigrants (e.g., Lobeliaceae and Gesneriaceae) have not only developed unusual arborescent forms but have speciated extensively. Much of the flora is adapted to the colonization of lava flows on new islands and volcanoes where the ecosystems characteristically develop around the two principal major forest trees, Metrosideros collina (Myrtaceae) and Acacia $k o a$ (Leguminosae). Many of the secondary trees of these developing forests serve as hosts for Drosophila; of greatest importance are trees of several genera of the families Araliaceae and Lobeliaceae in addition to Acacia, 


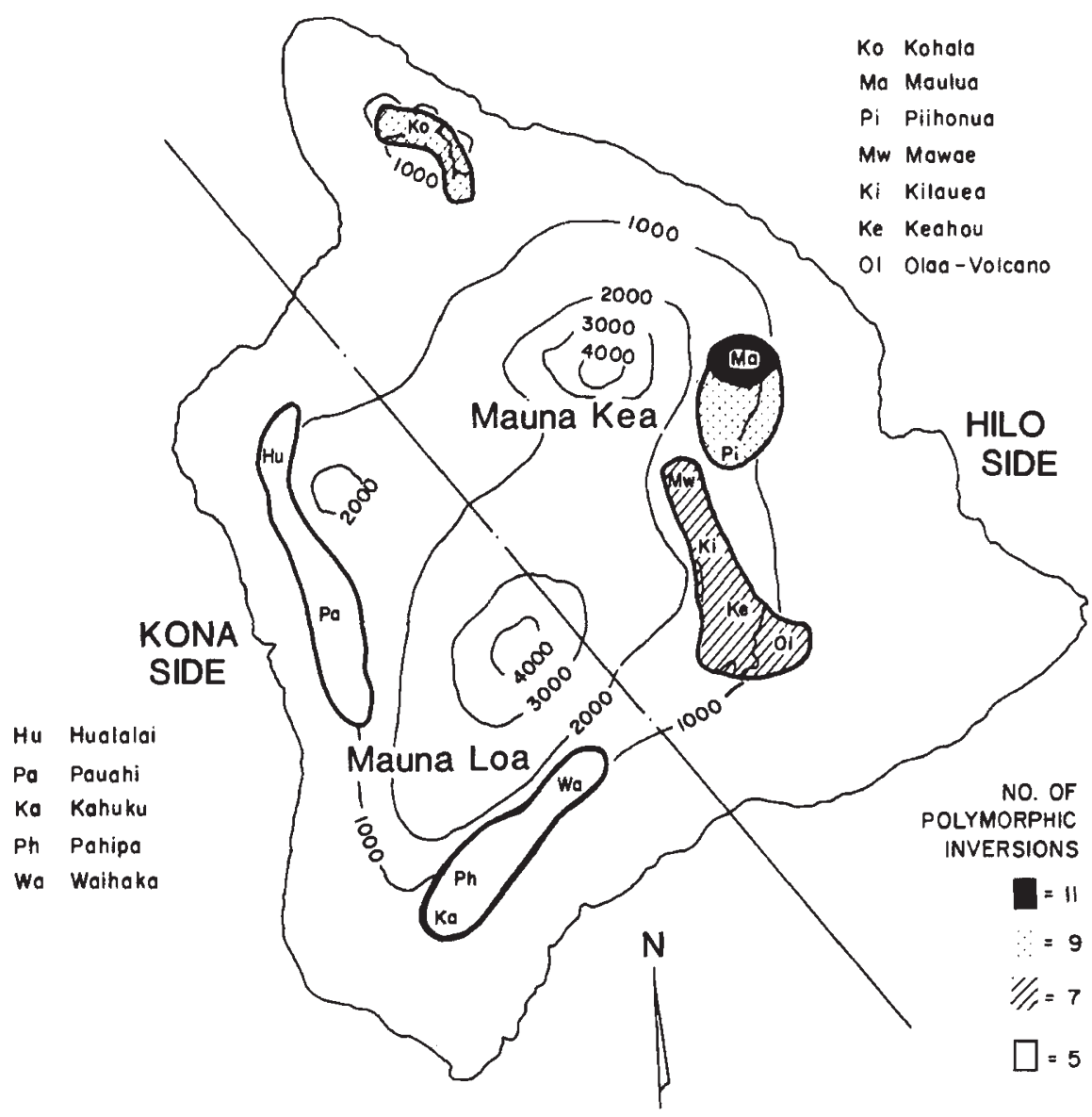

ISLAND OF HAWAII

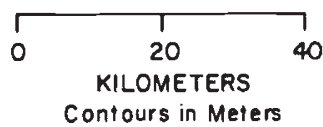

FIG. 2.-Island of Hawaii. The diagonal line separates Kona-side and Hilo-side populations of $D$. silvestris. Collecting localities and inversion frequencies of this species are given.

Myoporum, Freycinetia, Wikestroemia, Sapindus, Charpentiera and Pisonia.

Location of the breeding sites of the Hawaiian drosophilids has been quite successful. The small number of species dealt with in this review belong to a large chromosomally characterized group of about 110 species of Drosophila (subgenus Drosophila) loosely called the "picture-winged fiies". This group is only a small portion of the total fauna of the family Drosophilidae of the islands, which may ultimately number 800 species. Most picture-winged species are morphologically distinct from one another and have very large body sizes with long developmental times and sparse 
natural populations. The breeding sites of a majority of these species, however, are precisely known. Oviposition sites tend to be somewhat specialized, although most of the species breed on decaying bark or branches or on slime fluxes of the host tree.

Many of the tree species utilized are themselves rare and local in their distributions. Their dispersal over the new lava flows has a considerable stochastic element in it, that is, there are areas of local abundance separated by well-developed and extensive forests from which a host species may be virtually absent. The distribution of the fly species directly reflects the haphazard ranges of the rare host plants. Human intervention through agriculture and ranching has increased the rarity of some species but the phenomenon of strict localized foci of distribution is clearly an original and natural one, and has not been induced by man.

\section{Drosophila silvestris}

\section{(i) Distribution and ecology}

This is one of approximately 27 species of picture-wings that have been recorded from the Big Island. Special attention has been given to population study in this species. As all but one of the 27 , silvestris is found only on the Big Island but it shows strong chromosomal, morphological, behavioural and electrophoretic similarity to four other species. These are (1) its broadly sympatric relative on the Big Island, $D$. heteroneura (Perkins) and three strictly allopatric species, (2) D. planitibia (Hardy) of east and west Maui, (3) D. differens Hardy and Kaneshiro of Molokai and, slightly more distantly, (4) D. hemipeza (Hardy) of Oahu.

This very distinctive group of species are all dependent on locally rare arborescent lobeliads of the genus Clermontia (see fig. 4). Oviposition takes place on the decaying branches. Like some other new species from the island of Hawaii, occasional specimens of silvestris have been reared from host plants belonging to other families; these include Cheirodendron and Acacia koa. Single undersized specimens were reared from the fern Marattia and Metrosideros collina. This slight tendency towards generalism of oviposition site does not appear to be very significant for the distribution of the species and Clermontia remains the principal host.

Clermontia species and $D$. silvestris occur on all five volcanoes of the island of Hawaii. They are not only spotty in distribution, as described above, but suitable host species rarely occur below about $1000 \mathrm{~m}$ elevation and are absent from areas of low rainfall not only at the favoured altitude but also higher elevations as well. Thus, the hosts of the species decline again at altitudes above $1600 \mathrm{~m}$.

\section{(ii) Population samples}

Obtaining substantial population samples (e.g., 100 to 200 specimens) of a single species of Hawaiian picture-winged Drosophila is a very difficult matter. Indeed, most species have been collected in only very small numbers, even if the host plants are known and conditions appear to be favourable. More than any other single factor, this apparent rarity has limited quantitative studies of the natural population genetics of these 
species. In $1971, D$. silvestris was chosen, among a small number of other Big Island species, for detailed study. Like the other four species in this planitibia subgroup cluster, populations of silvestris are sparse, with the evidence indicating that minor highly localized population flushes occasionally occur. Although no attempts have been made to obtain mark-releaserecapture census figures for this species, some exemplary collecting data are presented here which support the hypothesis of rarity discussed above (table 1).

TABLE 1

Numbers of individuals of D. silvestris and several other species of picture-winged Drosophila captured a baits on Mauna Loa, Hawaii (1971-1972)

\begin{tabular}{|c|c|c|c|c|c|c|c|c|c|c|c|}
\hline \multirow[t]{2}{*}{ Species } & \multicolumn{6}{|c|}{$\begin{array}{c}\text { Olaa Tract } \\
1150 \mathrm{~m}\end{array}$} & \multicolumn{5}{|c|}{$\begin{array}{c}\text { Kilauea Forest } \\
1600 \mathrm{~m}\end{array}$} \\
\hline & Apr & Jun & Sept & Dec & Jan & Total & Apr & Jun & Sept & Dec & Total \\
\hline silvestris & 0 & 3 & 0 & 5 & 0 & 8 & 38 & 107 & 103 & 164 & 412 \\
\hline heteroneura & 1 & 1 & 3 & 7 & 3 & 15 & 0 & 0 & 0 & 0 & 0 \\
\hline setosimentum & 52 & 17 & 131 & 90 & 171 & 461 & 0 & 0 & 1 & 1 & 2 \\
\hline Totals & 53 & 21 & 134 & 102 & 174 & 484 & 38 & 107 & 104 & 165 & 414 \\
\hline Man-hours collecting & 29 & 32 & 26 & 25 & 15 & 127 & 32 & 57 & 42 & 32 & 163 \\
\hline silvestris/man-hour & $0 \cdot 0$ & $0 \cdot 1$ & $0 \cdot 1$ & $0 \cdot 2$ & $0 \cdot 0$ & $0 \cdot 1$ & $1 \cdot 2$ & 1.9 & $2 \cdot 5$ & $5 \cdot 1$ & 2.5 \\
\hline
\end{tabular}

Collecting picture-winged Drosophilas in the rainforests of the Big Island is generally done as follows. A broad search is instituted for the host plants following which the understory vegetation up to $2 \mathrm{~m}$ is closely scrutinized for flies resting in characteristic places. If specimens are thus located without bait, a return trip to the area is planned by a team of 3-5 collectors. Each person establishes a central point and sets out 15-20 approximately $1 \mathrm{cc}$ aliquots of fermented banana bait in a circle roughly $15 \mathrm{~m}$ in diameter. This bait is placed on the rhaches of tree ferns and on smooth low horizontal branches. Since about 1976, each person has also routinely set out about six thin plastic sponges attached to plants. These are saturated with a bait made from commercial mushrooms fermented with baker's yeast. The collector makes frequent rounds of his area for about three hours in the morning and again in the afternoon, capturing flies on or near the bait by imprisoning each specimen individually under a glass vial. A simple "specimens per man-hour" is used as a rough measure of species abundance.

Exemplary data involving $D$. silvestris are presented in table 1. Clearly, D. silvestris is exceedingly rare at Olaa Tract, Hawaii Volcanoes National Park, where intensive collections were particularly directed to obtaining population samples of $D$. setosimentum (see Carson and Johnson, 1975). At $1150 \mathrm{~m}$, Olaa Tract is close to the lower altitudinal limit for silvestris $(0 \cdot 1$ per man-hour). Nevertheless, in 1976 , a population flush occurred at one site in particular. In 44 man-hours, 149 specimens were obtained ( 3.4 per man-hour). In 1978, this had dropped to 1.3 (51 man-hours: 64 specimens). In 1979, 39 specimens were caught $(1.6 / \mathrm{man}$-hour) and in 1980,38 specimens $(0.6 /$ man-hour $)$. In 1981 , only 1 specimen was taken in 38 man-hours, indicating a return to the level of 1971-72.

At higher altitude (Kilauea Forest, table 1), silvestris appears to have larger and temporally more stable populations, although the effort necessary 


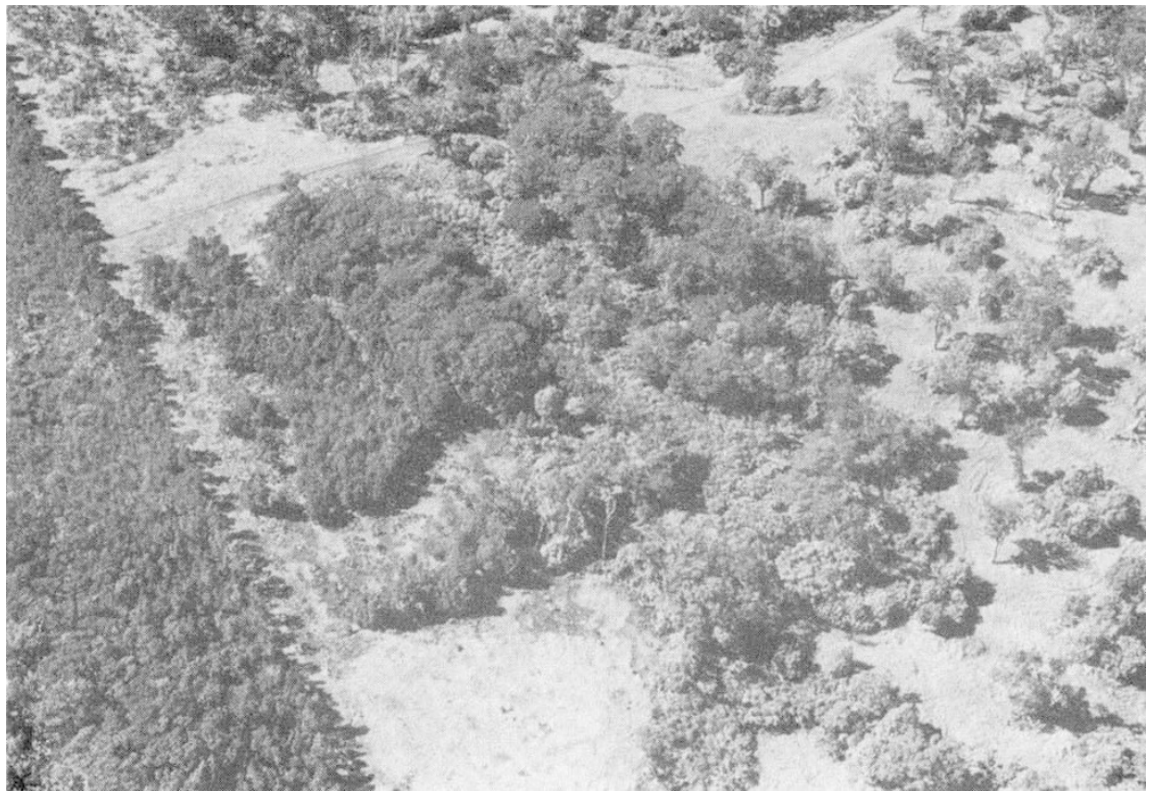

Fig. 3.-Air photograph of the Kahuku Ranch area at the southern end of Hawaii. Portions of the area have been cleared for pasture but several heavily forested areas remain as "ranch kipukas". The line to the right is the edge of the Ka'u Forest Reserve. Photograph by James Jacobi, U.S. Fish and Wildlife Service.

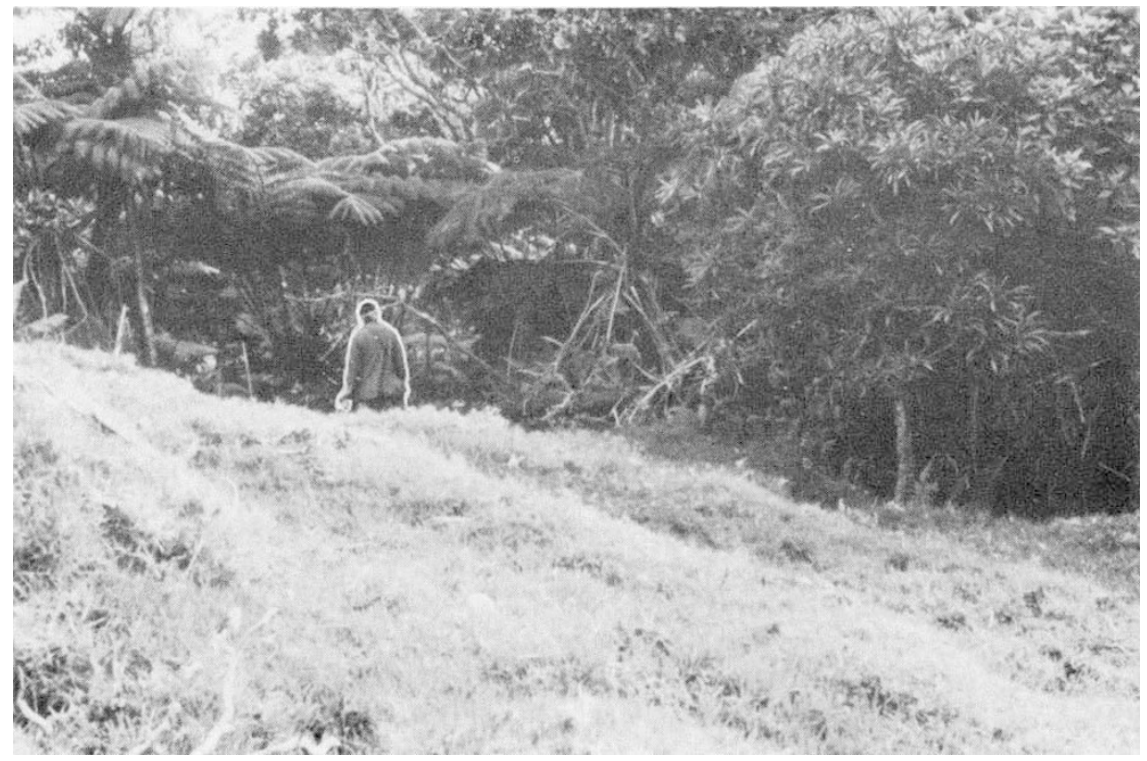

FIG. 4.-The interface between pasture-grass and a "ranch kipuka" at Kahuku Ranch. A specimen (about $3 \mathrm{~m}$ high) of Clermontia coerulea is shown at the right. The human figure at left is outlined to give scale. Photograph by K. Y. Kaneshiro. 
to obtain specimens is still quite great. When the number of specimens exceeds about three per man-hour, this is usually because one or more of the collectors has encountered a silvestris lek site. In such a place, up to about 20 males will set up individual display territories in the understory in a few adjacent tree-ferns or Clermontia trees. In such places, a considerable sample can be obtained without any bait at all. This kind of local abundance or discontinuous distribution is characteristic of many, if not most, picture-winged Drosophila species of Hawaii. Seasonal variations, if they occur, are eclipsed by other factors which affect the abundance of the species.

\section{(iii) The broad geographical setting}

Over the past twenty years, virtually all suitable silvestris habitats have been entered and worked by collectors on the Big Island with the result that the geographical distribution of the species is well known (fig. 2). Roughly, there are two areas on the Kona-side of the island ( $\mathrm{S}$ and $\mathrm{W}$ ) and three on the Hilo-side ( $\mathrm{N}$ and $\mathrm{E}$ ). There are important genetic differences between the populations of these two sides of the island, as will be discussed later. The Kona-side discontinuity of populations shown in fig. 2 may not be real as the intervening area has not been extensively collected. On the other hand, this southwest slope of Mauna Loa has been recently subjected to a series of lava flows from rifts, a number of which occurred in the early part of the twentieth century. This circumstance emphasizes that broad distributional maps of the kind presented in fig. 2 give a misleading impression of continuity between local populations. Thus, even within one small area of about $5000 \mathrm{~m}^{2}$ local mosaic patterns of rainfall, lava flows, host plant and lek distribution prevail. Effective population size appears to be kept small by sexual selection, as will be discussed later. All these things are working against any true panmixia in natural populations.

Superimposed on the above natural isolating factors are the activities of man which, in the last 100 years especially, have begun to alter the habitat of silvestris significantly. This is primarily due to lumbering activities at the higher altitudes and subsequent clearing of the forests for pasture. This has proceeded in a patchwork fashion and there nevertheless still remain large areas of relatively undisturbed forest on the island. Clearing for sugar cane planting, for example, is at lower elevations and does not reach into silvestris habitat. Furthermore, pasture clearance over the rugged lava, for example, results in many depressed pockets of dense vegetation being left more or less intact, even within pasture-land. The result is that pasture-making bulldozers often create man-made kipukas ("ranch kipukas") which mimic the natural ones created by lava flows (figs. 3 and 4).

To return to the broader geographical distribution of silvestris, one clearly disjunct population exists at the northern end of the island in the Kohala range (fig. 2). It is separated from the Kona-side populations by a xeric area about 40 kilometres wide which extends from sea level to the saddle between Mauna Kea and Mauna Loa. This is the "Parker Ranch" area of the $\mathrm{Big}$ Island. The original vegetation of this area, now mostly gone, consisted of a complex dry forest which nevertheless did not have elements which could have served as host plants for silvestris. A less extreme 
but nevertheless important ecological barrier exists between the southeast Kona-side populations and the eastern-most Hilo-side populations.

The Kohala populations are also isolated from the other Hilo-side populations on the east slope of Mauna Kea by an ecological barrier related to soils and rainfall. Finally, the small gap between the remaining two Hilo-side populations is not a significant one in any broad geographical sense. It was caused largely by recent lava flows (about 1885) from Mauna Loa overlapping the older Mauna Kea flows and ash deposits.

As mentioned earlier, the somewhat rarer species $D$. heteroneura is found sympatrically with silvestris (see fig. 2) at a number of sites, specifically at $\mathrm{Hu}, \mathrm{Pu}, \mathrm{Ka}, \mathrm{Wa}, \mathrm{Ol}, \mathrm{Ke}$, and $\mathrm{Pi}$. The most important exception is the Kohala range, where heteroneura has never been taken. This fact will acquire importance later in the discussion when it becomes apparent that the Kohala population of silvestris can be identified as the locus of a crucial genetic change in a secondary sexual character of males. The point to be noted here is that this is an area where silvestris is not sympatric with heteroneura or any species which could provide competing courtship opportunities. The latter species rarely outnumbers silvestris and this only occurs at lower elevations. Although silvestris may be obtained up to $1700 \mathrm{~m}$ altitude, it is not accompanied by heteroneura, which ends at about $1300 \mathrm{~m}$. These facts are exemplified by the Mauna Loa data given in table 1.

\section{(iv) Morphological variation}

The older chromosomal and electrophoretic information on this species (Sene and Carson, 1977; Craddock and Johnson, 1979) must be reexamined in view of the recent morphological data of Carson and Bryant (1979) and Carson et al. (1982). The significant new morphological finding involves a non-overlapping quantitative difference in number of cilia on the foreleg of males from the two sides of the island. The dorsal surface of tibia of the foreleg of males in the planitibia subgroup is adorned with a series of long cilia. These occur roughly in two marginal rows with a bare area in between. This is strictly a secondary sexual character. This surface of the male leg is brought into vibratory contact with the dorsal surface of the female's abdomen during a crucial late stage in the complicated courtship procedure (Spieth, 1978). The ancestrally-positioned species on Oahu, Maui and Molokai and D. heteroneura of the Big Island have 36-40 of these cilia arranged in the two marginal rows with only an occasional cilium in the "bare" area. The leg of Kona-side silvestris males resembles these species but shows a modest increase in the number of cilia (the total is about 47). The central bare area, however, is unchanged.

Hilo-side silvestris, on the other hand, shows a very large and striking difference from Kona-side silvestris and the other species (Carson and Bryant, 1979; Carson et al., 1982). Thus, the area of the tibia that is bare in these other populations and species has become adorned with an additional 25-30 of these large cilia. Along with an increased number in one of the marginal rows, this results in a tibia having about 88 cilia on the average (fig. 5). In this figure, the results of sample counts from six Hilo-side silvestris localities are summarized. It will be seen that the Kohala and Piihonua samples have smaller bristle totals than the samples from the other four localities. This is a statistically significant difference (Carson et 


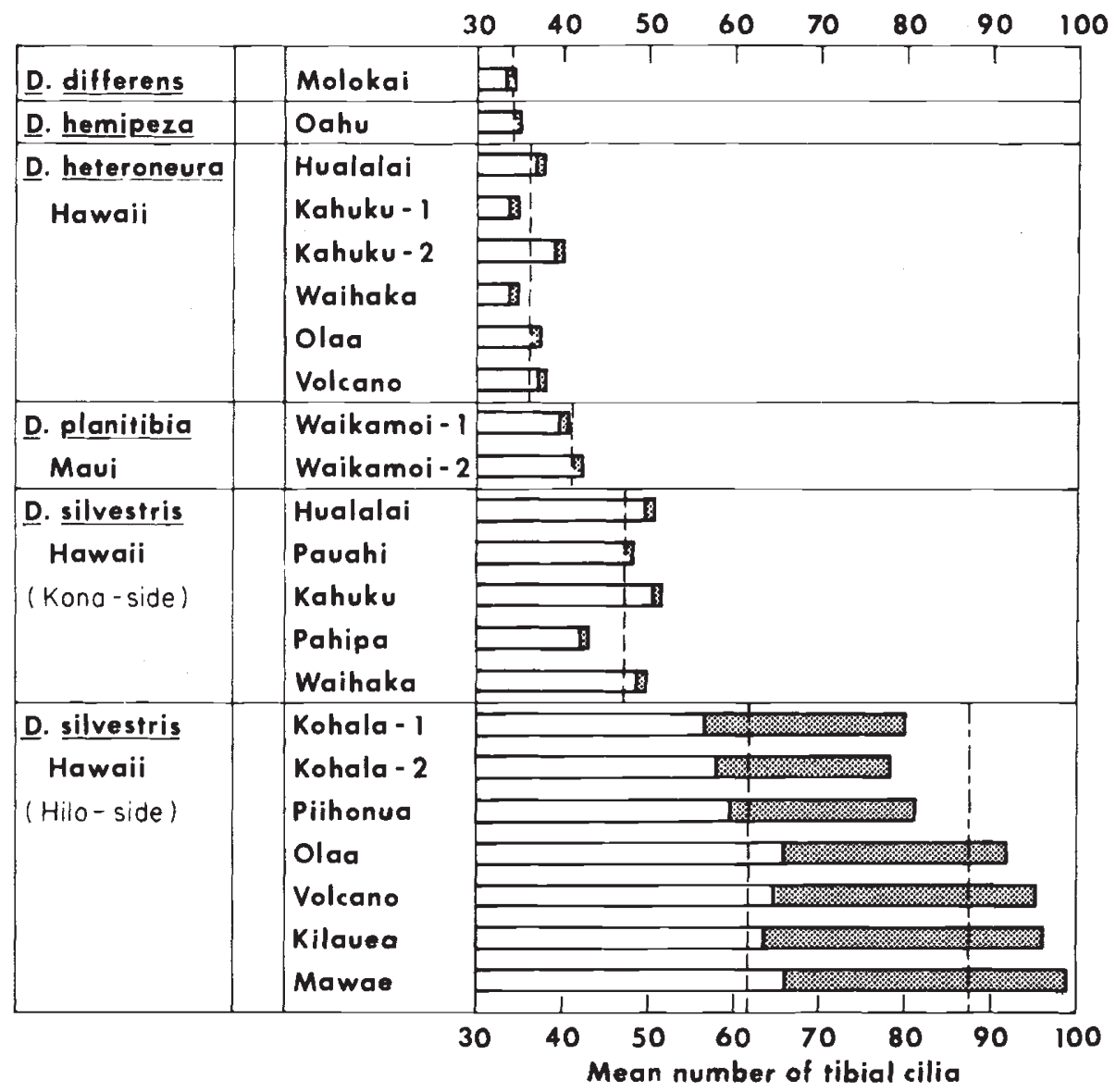

FIG. 5.-Mean numbers of cilia on dorsal surface of the tibia of the male foreleg in species of the planitibia subgroup. Vertical broken lines represent weighted means of population means of rows 5 and 6; the vertical line at the right of Hilo-side silvestris represents the mean with row $5 \mathrm{a}$ (the middle row) added. Cross-hatching in bars represent cilia from row 5a. Most of the specific localities may be located on fig. 2. (After Carson et al., 1982.)

al., 1982). The lava flows of the Kohala range are geologically much older than the rest; behavioural data, to be adduced later, also suggest that this area houses the oldest of the Hilo-side populations. The suggestion is offered that the bristle character has become intensified in these newer populations.

The extent of the difference in bristles is such that there is no overlapping between Kona-side and Hilo-side males; on morphological grounds, therefore, any single male can be diagnosed as to which side of the island it comes from. Indeed, this kind of discontinuous difference has frequently served as a criterion for recognizing two such entities as different species. Such a taxonomic judgment has been avoided in the present case and the two distinct types are referred to simply as Kona-side and Hilo-side respectively. 
In view of the chromosomal, electrophoretic, hybridization and behavioural data now to be presented, the morphological facts noted above gain a great importance. Since Oahu, Molokai and Maui species of the subgroup as well as heteroneura of the Big Island have the smaller number of male tibial bristles, one may conclude that Kona silvestris is retaining this ancestral condition and is therefore the phylogenetically older of the silvestris populations on the two sides of the island. Conversely, this argument permits us to view the fore-tibia of Hilo silvestris as representing an evolutionary novelty or new embellishment of a character which had remained stable through a series of speciation events involving four islands and somewhat more than one million years of evolution. Accordingly, this most recent novelty in Hilo silvestris and thus the six populations on the northeast side of the island (fig. 2), have become the focus of special attention.

\section{(v) Chromosomal variation}

To put these populations in perspective, it is of interest to review the chromosomal polymorphism in silvestris and related species. The four Molokai, Maui and Big Island species are all homosequential, that is, they share a common standard polytene sequence for each of the five major chromosomes. Metaphase groups do not appear to be different among any of these species (Clayton and Wheeler, 1975; Clayton, 1976). Whereas the Maui and Molokai species are monomorphic, both Big Island species display chromosomal polymorphism (fig. 6). D. heteroneura, however, is polymorphic for only one inversion $(3 \mathrm{~m})$, which is nevertheless found in all populations of the species. $D$. silvestris displays a $3 m$ polymorphism having identical break points to those of the heteroneura inversion; the $3 \mathrm{~m}$ inversion polymorphism is also ubiquitous in silvestris populations from both sides of the island.

In addition to the $3 m$ inversion, silvestris is polymorphic for 10 additional inversions (figs. 2 and 6). Several points about the distribution of these inversions are of special interest. First, as shown in fig. 2, Kona silvestris is less polymorphic than Hilo silvestris, with the greatest number of inversions (11) segregating in the Maulua population on Mauna Kea. As presented in fig. 6 , the data suggest an accumulation of inversions in the newer silvestris populations on the Hilo side. At one extreme, the very wide-spread $3 m$ (all heteroneura and silvestris populations) may be judged as the oldest, whereas $X t^{3}$ and $4 p^{3}$, endemic to Maulua, appear to be the youngest (Carson, 1981).

Inversion $3 m$ and the others shared by both Kona and Hilo silvestris show altitudinal clines on both sides of the island (fig. 7). In two transects on the Kona side (on Hualalai, and at Pahipa-Kahuku) and one on the Hilo side (Kilauea-Keahou-Volcano) the frequencies of the inversions common to populations of the two sides shift with altitude. Thus, both the derived high-bristle populations of Hilo and the more ancestral low-bristle populations of Kona have a series of genetic elements (inversions) in common. These genetic elements thus vary with the environment in a strikingly similar manner on the two sides of the island.

As the inversions are monophyletic events, their origin must pre-date the differentiation of the two bristle populations, again emphasizing the 


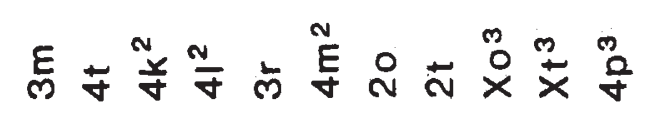

\title{
DIFFERENS MOLOKAI \\ (20)
}

\section{PLANITIBIA \\ MAUI \\ (46)}

\section{HETERONEURA}

HAWAII

(214)

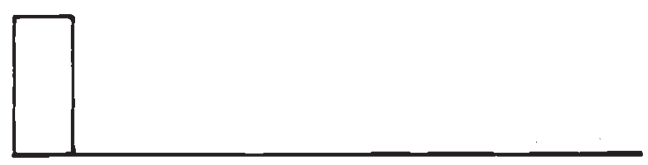

\section{SILVESTRIS}

\author{
HAWAII \\ HUALALAI \\ (162)
}

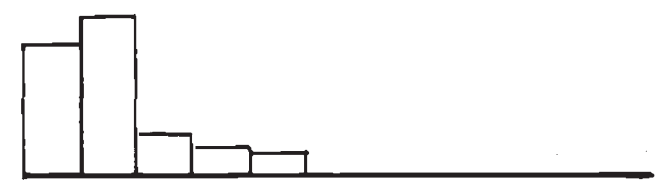

\section{SILVESTRIS}

$$
\begin{gathered}
\text { HAWAII } \\
\text { MAWAE-9 } \\
\text { (172) }
\end{gathered}
$$

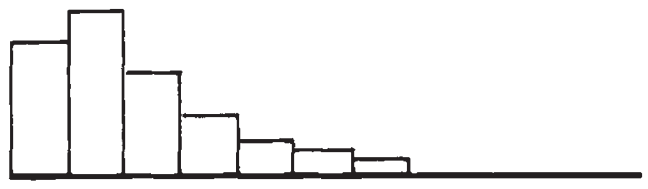

\section{SILVESTRIS}

HAWAII

MAULUA

(118)

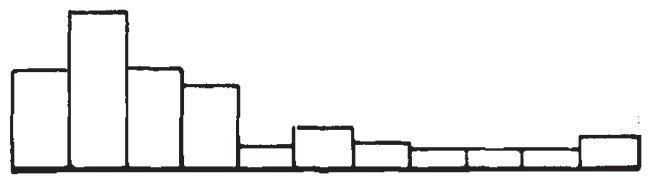

FIG. 6.-Frequency of inversions in various populations of planitibia subgroup species. The numbers of wild chromosomes examined are given in parentheses. For geographical locations, see fig. 2. 


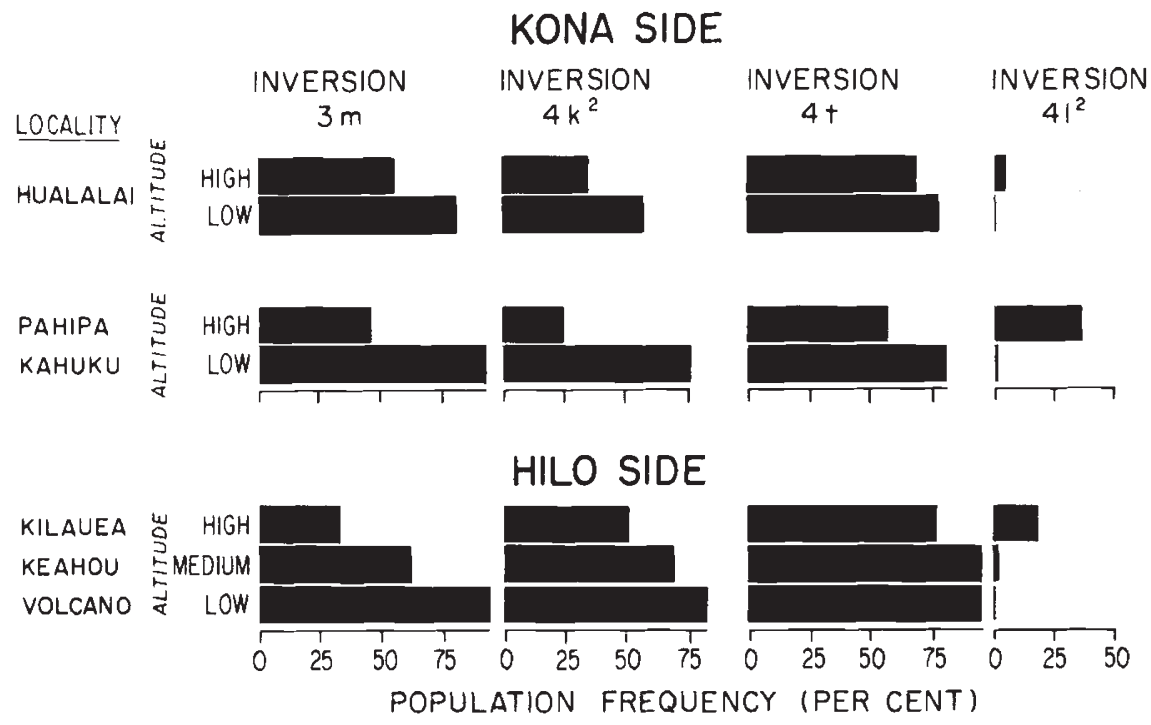

FIG. 7.-Parallel altitudinal clines of inversion frequencies in populations of $D$. silvestris from the two sides of the island of Hawaii. Populations can be located on fig. 2. (After Carson and Bryant, 1979.)

phylogenetic newness of the bristle character of Hilo-side populations. Indeed, the inversions seem to respond ecotypically but this response is occurring in parallel fashion in the two completely separate allopatric segments of the species. Such inversion-frequency changes, therefore, appear to represent a component of ecogenetic adjustment rather than an indication of incipient speciation. We will return to this argument after considering other aspects of the biology of these populations.

\section{(vi) Biochemical variation}

Allozymic variation in $D$. silvestris and several of its relatives has been studied by Craddock and Johnson $(1974,1979)$ and Sene and Carson (1977). Populational heterozygosity is moderate; for Kilauea Forest samples of $D$. silvestris it is 0.124 ; this is not very different from other populations of this and the other species. The most striking fact to emerge from these studies is the great overall electrophoretic similarity not only among all local populations of silvestris but also between this latter species and its sympatric associate heteroneura (fig. 8). Nei's similarity coefficient between the species is $0.939 \pm 0.01$. This is not very different from those observed within silvestris $(0.961 \pm 0.01)$ or within heteroneura $(0.949 \pm$ $0 \cdot 02$ ). No diagnostic (fixed) alleles have been found.

It has been suggested (Carson, 1978) that the similarity between silvestris and heteroneura may be due to the recent speciation event in this case. This may be so, but more importantly, the data can be interpreted to mean that electrophoretic similarity is an unreliable measure of overall genetic similarity. This is emphasized not only by the many morphological and behavioural differences between these species which have a genetic basis 

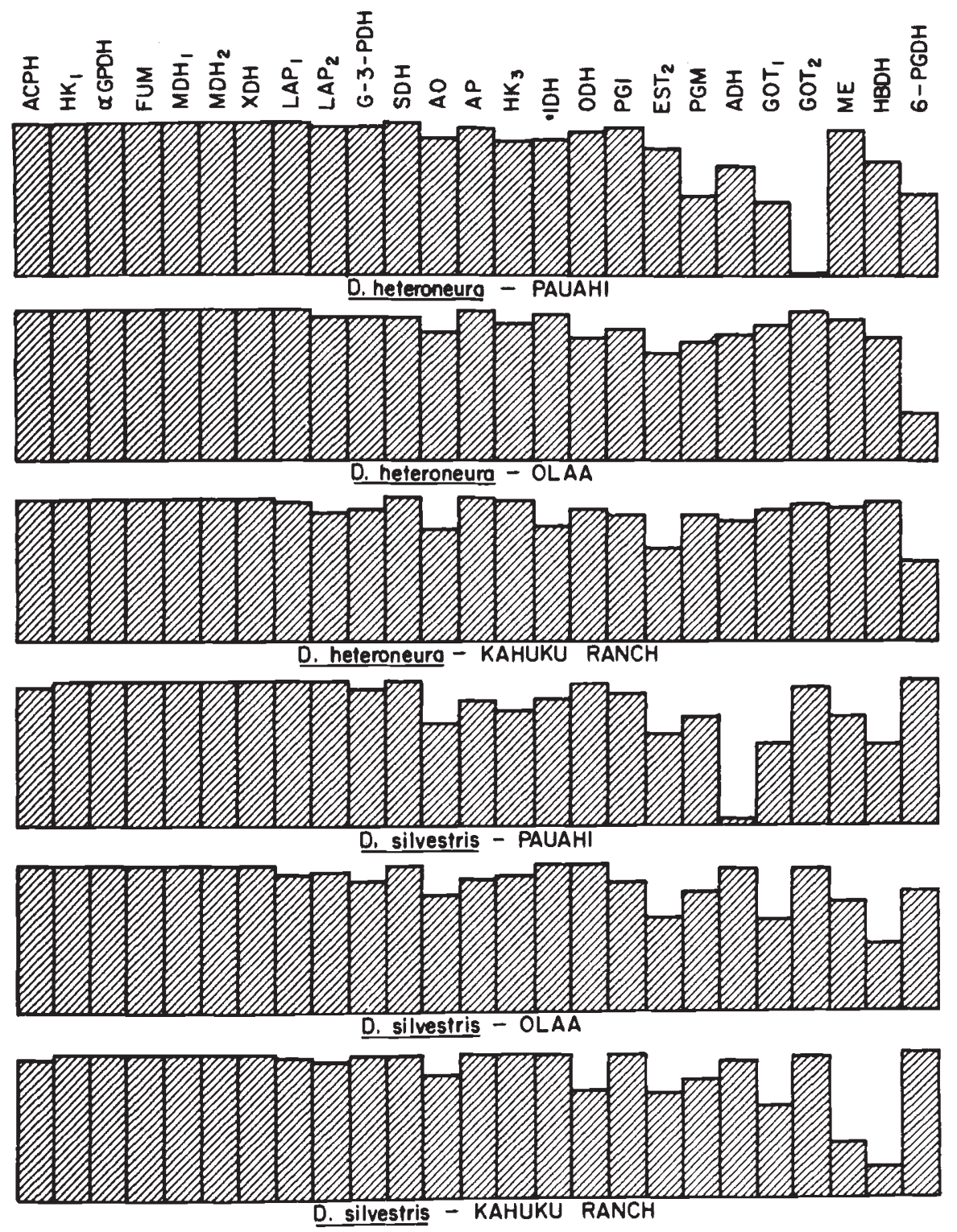

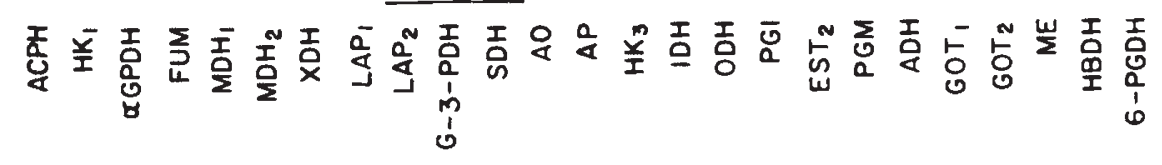

FIG. 8.-Frequency of allele 1.0 at each of 25 allozymic loci in Drosophila heteroneura and Drosophila silvestris at each of three localities on the island of Hawaii. For geographical locations, see fig. 2. (From Sene and Carson, 1977.) 
but also by recent biochemical comparisons of single-copy DNA fractions. Thus, Hunt et al. (1981) have demonstrated that substantial DNA differences exist. These are not reflected in the data from soluble proteins.

Even those electrophoretic differences in gene frequency that do exist are clearly not related to past or incipient speciation events. For example, the near-replacement of the otherwise common allele of $\mathrm{ADH}$ in silvestris in the Pauahi-Hualalai area (fig. 8) does not parallel the Kona-side/Hiloside tibial cilia difference. Likewise, the GOT-2 allele shift in $D$. heteroneura appears only in the Pauahi population. Sene and Carson have interpreted these changes as due to chance at the time of founding.

Some of the interpopulation differences in electrophoretic allele frequencies may be due to linkage with inversions which are shifting altitudinally. For example, there is a striking change between Kahuku and Pahipa in three fourth chromosome inversion frequencies of $D$. silvestris (fig. 7). Two allozyme loci show altered frequencies in these same populations; both are located on chromosome 4 . Thus, the common (1.00) allele of malic enzyme (ME) which has a frequency of 0.361 at Kahuku rises to 0.833 at Pahipa which is $400 \mathrm{~m}$ higher in altitude. Likewise, the common allele of octanol dehydrogenase (ODH) rises from 0.737 to 0.917 . These differences, therefore, may be part of the ecotypic shift mentioned above, involving blocks of polygenes located within or adjacent to the inversions concerned.

\section{(vii) Mating behaviour}

Craddock (1974), Ahearn et al. (1974), Val (1977), Kaneshiro (1976, 1980), Kaneshiro and Val (1977), Carson (1978) and Spiess and Carson (1981) have dealt with the subject of reproductive behaviour and isolation among the species of the planitibia subgroup. A complex pattern of premating incompatibilities exists among the various populations and species. On the other hand, with the exception of crosses involving $D$. planitibia (Hardy and Kaneshiro), hybrid viability and fertility between most of the entities is very high. This has led to the view that shifts in the genetic basis of mating behaviour have been one of the most important types of change which have historically occurred between these various populations. Many of the shifts occur in allopatry, as will be discussed later.

Kaneshiro (1976), Ohta (1978), and Watanabe and Kawanishi (1979) have presented data which show that, when two populations of the same or very closely related species are compared, the females of one of the populations frequently tends to be much more discriminatory in acceptance of males. In the pairwise comparisons involving such mating choice among Hawaiian populations, that with the higher female discrimination comes from the geologically older area. In the Hawaiian situation, each volcano has a successively younger age, permitting unequivocal inference as to which is the older area. This correlation has led both Kaneshiro and Ohta to suggest that their behavioural data could be used to indicate the direction of evolution. They propose that the phylogenetically older populations are characterized by females with the higher degree of discrimination. Although Watanabe and Kawanishi have data which are directly comparable and supplementary to those of Kaneshiro and Ohta, they have chosen to argue, without outside data, that the older populations have females with the least 
discrimination. Therefore, they infer a direction of evolution which, of course, is just the reverse of that suggested by Kaneshiro and Ohta. The facts of the geological age of the relevant volcanoes in Hawaii are based on powerful, mutually supporting data from $\mathrm{K}-\mathrm{Ar}$, magnetic declination and erosional features. Accordingly, the data provide outside information that the direction of evolution proposed by Kaneshiro and Ohta is the correct one.

Kaneshiro and Kurihara (1982) have studied female mating discrimination among a series of Kona-side and Hilo-side populations of $D$. silvestris (table 2). Most crucial for this review is the fact that the populations with

TABLE 2

Mate preference experiments among six populations of D. silvestris (from Kaneshiro and Kurihara, 1982)

\begin{tabular}{|c|c|c|c|c|c|c|}
\hline$\delta$ & १ & $n$ & $\begin{array}{c}\text { Freq. } \\
\text { homogamic }\end{array}$ & $\begin{array}{c}\text { Freq. } \\
\text { heterogamic }\end{array}$ & $I^{*}$ & $C^{\dagger}$ \\
\hline $\begin{array}{l}\text { Hualalai }(\mathrm{Hu}) \\
\text { Pauahi }(\mathrm{Pa})\end{array}$ & $\begin{array}{l}\mathrm{Hu} \mathrm{Pa} \\
\mathrm{Pa} \mathrm{Hu}\end{array}$ & $\begin{array}{l}36 \\
35\end{array}$ & $\begin{array}{l}0.31 \\
0.80\end{array}$ & $\begin{array}{l}0.69 \\
0.20\end{array}$ & $\begin{array}{l}-0.38 \\
+0.60\end{array}$ & $\begin{array}{l}-2 \cdot 28 \\
+3 \cdot 55\end{array}$ \\
\hline $\begin{array}{l}\text { Hualalai (Hu) } \\
\text { Kahuku (Ka) }\end{array}$ & $\begin{array}{l}\mathrm{Hu} \mathrm{Ka} \\
\mathrm{Ka} \mathrm{Hu}\end{array}$ & $\begin{array}{l}35 \\
33\end{array}$ & $\begin{array}{l}0.14 \\
0.82\end{array}$ & $\begin{array}{l}0 \cdot 86 \\
0 \cdot 18\end{array}$ & $\begin{array}{l}-0.72 \\
+0.64\end{array}$ & $\begin{array}{l}-4 \cdot 26 \\
+3 \cdot 68\end{array}$ \\
\hline $\begin{array}{l}\text { Pauahi (Pa) } \\
\text { Kahuku (Ka) }\end{array}$ & $\begin{array}{l}\mathrm{Pa} \mathrm{Ka} \\
\mathrm{Ka} \mathrm{Pa}\end{array}$ & $\begin{array}{l}33 \\
37\end{array}$ & $\begin{array}{l}0.30 \\
0.86\end{array}$ & $\begin{array}{l}0 \cdot 70 \\
0 \cdot 14\end{array}$ & $\begin{array}{l}-0.40 \\
+0.72\end{array}$ & $\begin{array}{l}-2 \cdot 30 \\
+4 \cdot 38\end{array}$ \\
\hline $\begin{array}{l}\text { Hualalai (Hu) } \\
\text { Kohala (Ko) }\end{array}$ & $\begin{array}{l}\mathrm{Hu} \mathrm{Ko} \\
\mathrm{Ko} \mathrm{Hu}\end{array}$ & $\begin{array}{l}39 \\
35\end{array}$ & $\begin{array}{l}0.46 \\
0.71\end{array}$ & $\begin{array}{l}0.54 \\
0 \cdot 29\end{array}$ & $\begin{array}{l}-0.08 \\
+0.42\end{array}$ & $\begin{array}{l}-0.50 \\
+2 \cdot 48\end{array}$ \\
\hline $\begin{array}{l}\text { Kohala (Ko) } \\
\text { Piihonua (Pi) }\end{array}$ & $\begin{array}{l}\text { Ko Pi } \\
\text { Pi Ko }\end{array}$ & $\begin{array}{l}51 \\
41\end{array}$ & $\begin{array}{l}0.47 \\
0.59\end{array}$ & $\begin{array}{l}0.53 \\
0.41\end{array}$ & $\begin{array}{l}-0 \cdot 06 \\
+0 \cdot 18\end{array}$ & $\begin{array}{l}-0.43 \\
+1.15\end{array}$ \\
\hline $\begin{array}{l}\text { Kohala (Ko) } \\
\text { Olaa (Ol) }\end{array}$ & $\begin{array}{l}\text { Ko Ol } \\
\text { Ol Ko }\end{array}$ & $\begin{array}{l}40 \\
42\end{array}$ & $\begin{array}{l}0.23 \\
0.69\end{array}$ & $\begin{array}{l}0.77 \\
0.31\end{array}$ & $\begin{array}{l}-0 \cdot 54 \\
+0 \cdot 38\end{array}$ & $\begin{array}{l}-3 \cdot 42 \\
+2 \cdot 46\end{array}$ \\
\hline $\begin{array}{l}\text { Piihonua (Pi) } \\
\text { Olaa (Ol) }\end{array}$ & $\begin{array}{l}\mathrm{PiOl} \\
\mathrm{Ol} \mathrm{Pi}\end{array}$ & $\begin{array}{l}38 \\
37\end{array}$ & $\begin{array}{l}0.29 \\
0.68\end{array}$ & $\begin{array}{l}0.71 \\
0 \cdot 32\end{array}$ & $\begin{array}{l}-0.42 \\
+0.36\end{array}$ & $\begin{array}{l}-2.59 \\
+2.19\end{array}$ \\
\hline
\end{tabular}

* Charles-Stalker Isolation Index.

$+C=2 \sqrt{n}(p-0 \cdot 5)$. At the 5 per cent confidence interval, the null hypottiesis that mating is random is accepted when $-1.96<C<+1.96$.

the greatest female discrimination on the Big Island are those from Hualalai Volcano, a population which belongs to the low-bristle Kona-side section of the species. It will be recalled that Kona-side populations have been judged ancestral on morphological grounds. When pairwise comparison of Hualalai behaviour is made with Kohala (table 2), the Hualalai females are the more discriminatory. When Kohala populations, furthermore, are compared with those from Olaa, females of the latter are less discriminatory. These facts suggest that the novel increase in bristle number first occurred in the Kohala mountain populations. Again, as the lava flows around Mauna Loa are among the newest in the archipelago, far younger than Kohala, the direction of evolution as measured by behaviour derives support from the geological data. It should further be noted that Kaneshiro and Kurihara's data show that Hualalai $\rightarrow$ Pauahi $\rightarrow$ Kahuku also form a behaviourally differentiated directional series of populations on the Kona side of the island. This permits the inference that there were two lines of 
descent from populations originating in Hualalai and spreading in different directions from there.

The "Kaneshiro effect" (ancestral females are more discriminatory than derived) is also supported by data on the behaviour of laboratory strains of $D$. silvestris and other species. Ahearn $(1980 a)$ tested two strains of silvestris collected in the same geographical area (Kilauea). The older of these had experienced many drastic population bottlenecks over its long history in the laboratory, whereas the younger had been maintained in a large population. Ahearn made reciprocal tests of these stocks and found that the females of the older, periodically attenuated one, very readily accept males of the other although the reverse is not true. She concluded that the older laboratory strain had been subjected to genetic drift which effected a reorganization of behavioural elements in a manner comparable to that suggested by Kaneshiro for events following the founder effect in natural populations.

Arita and Kaneshiro (1979) describe a similar phenomenon in $D$. adiastola of Maui. Newly-established stocks, which had been purposely kept large and outbred are characterised by discriminatory females relative to a population forced several times through a single pair of flies. Furthermore, Kaneshiro (1980) has recalculated some of the experimental data of Powell (1978) on $D$. pseudoobscura. Powell forced laboratory strains through a series of founder events and found that a premating isolation had developed in several of the strains so treated. Kaneshiro's analysis of Powell's data reveal that a large component of this isolation consists of lowered female discrimination following the drift events. The hypothesis that these shifts are based on alterations of the genetic balances underlying the sexual selection system is under active investigation at the present time.

The data on Hualalai and Kohala silvestris, suggesting that Hualalai still harbours remnants of an older population is paralleled by data from another species, D. setosimentum (Carson and Johnson, 1975). As in silvestris, there is a distinct Kona-side entity, showing a number of chromosomal (and in this case also electrophoretic) differences from the Hilo-side populations. These Kona-side populations display a fixed gene order in chromosome 2 which matches that of the putative ancestral species, $D$. adiastola of Maui (Carson and Johnson, 1975). Elsewhere on the Big Island, both $D$. setosimentum, a close partially sympatric relative, and $D$. ochrobasis, have different fixed chromosome inversions in chromosome 2. Clermontia, which is a major host for all three of these species, as well as silvestris and heteroneura and their putative ancestors, is especially abundant on the slopes of Hualalai, whereas the older Kohala volcano has less diversity. Accordingly, it is tempting to suggest that Hualalai was especially suitable for the establishment of successive founders coming from the Maui complex. These species may well have been preadapted to Clermontia as a host.

\section{(viii) Hybridization}

Mention was made in earlier paragraphs of the fact that, with the exception of $D$. planitibia of Maui, considerable interspecific fertility exists among these species. This situation is especially striking in the partially sympatric pair of species silvestris and heteroneura. Furthermore, no hybrid 
sterility or postmating breakdown has been encountered in any interpopulation crosses within or between these two species, including crosses between Kona and Hilo types of $D$. silvestris (Craddock, 1974; J. N. Ahearn, unpublished).

The interfertility of these species has permitted an unusually sensitive exploration of the genetically based morphological differences between species and strains. Notable behavioural differences also exist but their inheritance has not been studied (Watson, 1979, 1980). Val (1977) made reciprocal crosses between heteroneura and silvestris. $F_{1}$ 's from both reciprocals are viable and fertile in both sexes, permitting an $F_{2}$ analysis of the inheritance of the many morphological and behavioural differences between the species. The initial hybridization between the species are difficult to obtain since premating incompatibilities are strong. Nevertheless, once a mating has occurred, progeny are numerous, vigorous, fertile and show normal sex-ratios. $F_{1}$ flies show much less behavioural discrimination than their parents (Ahearn, 1980 $b$ ).

Using Val's metrical data on females, Templeton (1977) estimated that the striking difference in head shape between the species was based on several autosomal loci combined with the effects of a sex-linked locus. Viewing all morphological characters segregating in the $F_{2}$ 's, Val estimated that the species differ at between 15 and 19 polygenic loci including one or more that are sex-linked. The allozymic similarity of these species should be recalled here. Obviously similarity coefficients based on soluble proteins do not reflect the extent of these morphological differences.

Bryant and Carson (1979) showed that the inheritance of the tibial cilia in this same cross shows an almost identical pattern of inheritance; it must involve several gene differences. These findings, showing that there is indeed considerable genetic difference between the species, are of interest in view of the complementary evidence that there are substantial differences in single-copy DNA between the species (Hunt et al., 1981). Electrophoretically-detected enzyme differences and cytologically-detected inversion differences are apparently less sensitive than morphology in reflecting early genetic change following speciation.

It is for this reason that attention has recently been focussed on the differences between Kona-side silvestris and the descendant Hilo-side populations of the same species. Preliminary analysis of crosses between the two kinds of silvestris shows that the tibial bristle differences in males are polygenically based. Carson and Teramoto (1980) and Spiess and Carson (1981) have demonstrated that a powerful system of epigamic sexual selection is operating in laboratory populations of $D$. silvestris. Such a system, resting on a polygenic basis, could be especially susceptible to shifts and changes in balance following founder events (Carson, 1978; Templeton, 1980; Lande, 1981). The facts lead us to emphasize the sexual environment as the crucial one which is vulnerable to alteration when a new population or species is founded.

\section{IMPLiCATIONS OF THE HAWAiIAN DROSOPHILA WORK FOR EVOLUTIONARY BIOLOGY}

Up to this point, the writer has attempted to report accurately the interpretative emphases of the various authors of the papers discussed. 
What follows is a personal attempt to take a somewhat broader view of the entire project on Hawaiian Drosophila and see if there are any general trends or aspects which may suggest new directions for evolutionary biology.

As has been expressed in Mueller-Dombois et al. (1981) the genetic population biology of insular organisms differs from continental populations in only one important way: island populations sequester less genetic variability. Local insular populations, however, can be fully as polymorphic genetically as any single local population of a widespread continental species. Accordingly, the demes of either island or continent are equally competent for adaptive evolution. Island populations have far fewer demes and thus an island species holds less variability.

In high-altitude oceanic archipelagos like Hawaii, many factors promote spatial isolation. New islands are formed; there are new volcanoes within islands. Lava flows destroy the old ecosystems as they provide substrates for new ones. Patterns of drought and rainfall shift in both the long and short term. Colonization by plants of the newer flows is accompanied by a large chance element. All of these things are of great importance to the genetic structure and the biological future of island organisms. The most striking mode of speciation is clearly allopatric: it involves the passing of a population through one or a few inter-island or inter-volcano founder individuals. Continual opportunity for resettling an area is made available to insular organisms by the mode of growth of a shield volcano.

Some island groups (genera) are highly speciose whereas others, evolving over the same time-scale, do not show this tendency. The speciose organisms may be considered the dynamic elements in the ecosystems in that the chance nature of the founder mode of speciation often permits them to enter a new niche rather than remain closely adapted to an old one. Whereas in the continents a deme is likely to be surrounded by other demes, the island deme often finds itself alone, with no source of immigrants nearby. This places a special premium on inbreeding and selection within the deme.

One of the important dimensions of the Hawaiian Drosophila work is that it permits, to some degree, the integration of macroevolution and microevolution. Following Dobzhansky's early lead, Drosophila workers have traditionally maintained a basically microevolutionary approach. The work has been centered largely on easily-reared species (i.e., species with generalist adaptations) which tend also to have vast continental distributions. The origin of most of these species appears to have been in the distant past, swallowed up in the intricacies of continental histories. Evolution in Hawaii is clearly circumscribed in space and time.

Although speculations have been attempted (e.g., Throckmorton, 1975), the fossil record of Drosophila and indeed the Diptera as a whole is quite inadequate as a basis for macroevolutionary surmises. As a result, speculations on origins are based on data on current distribution of specific and generic types and to some degree that of the host plants for the species.

Hawaii presents a set of oceanic islands in a linear series from older to younger so that evolutionary considerations or inferences can be begun either at the older or younger end of the chain. The most profitable approach seems to be to start at the younger end and extrapolate backward in time and space. On the new island of Hawaii, there are 27 species of the large picture-winged Drosophila flies which are living on an island that is less 
than a million years old. Nevertheless, the island has been able to acquire a complex set of environments and ecosystems (Mueller-Dombois et al., 1981).

The origin of most of these species can be traced by morphological and chromosomal characters to species found on older islands and volcanoes to the northwest. Neither morphology nor chromosome inversions provide, in themselves, unequivocal evidence on the direction of evolution.

But in Hawaii, a new dimension enters. Thus, inference of evolutionary direction can be made from the serial age of the islands and their overall relative youth compared with the continents at their periphery. In a broad way, this relationship with the continents has been used to set the direction of evolution of the Hawaiian fauna. It appears to have been derived from one or more continental sources rather than the reverse. As has been pointed out in previous reviews, once the direction of a chromosome inversion phylogeny is set by outside information, it forms an extensive temporal and spatial framework of stepwise relationships which, for many species groups at least, is consistent directionally within itself.

These basically macroevolutionary considerations set the stage for the consideration of population characteristics of single species in a manner which provides a special historical dimension rarely possible in modern population biology.

We are able to describe in Drosophila silvestris, endemic to the newest island, ten new gene arrangements due to inversions. Our ability to declare them "new" comes about through comparative cytological study of about a hundred other species. From that study, we know that these inverted segments are absolutely unknown outside the populations of silvestris. On the other hand, one may reverse the point of view. The alternate component sequence of a chromosomal polymorphism (the "standard" or uninverted) of each chromosome segment can be treated as a "primitive" sequence. This sequence can be identified in species from geologically much older islands. For example, Carson $(1973,1974)$ detailed a case wherein a derived gene arrangement (inversion $X t$ ) arose in a Maui-complex species $(D$. neopicta) about one and one-half million years ago. The derived gene arrangement $(X t)$ has become fixed in the populations of 11 additional species at the newer end of the archipelago. Several other inversions show a similar pattern and the data support these inferences. The species that still carry these polymorphisms are found together on the East Molokai volcano and one of them is endemic there. This allows the age of the island to be used as an estimate of the age of the polymorphic state. This adds a new dimension to the study of chromosomal morphism since other attempts to estimate ages of chromosomal polymorphisms have been poorly founded (e.g., Mayr, 1945). This appears to be a good example of the successful integration of macro- and micro-evolutionary approaches.

Most population biologists tend to consider novel adaptation to be a phenomenon which ultimately leads to speciation, that is, the species is viewed as an "adaptive device" (Dobzhansky, 1976). Contemplation of the Hawaiian data has led me to a view that separates speciation and adaptation as evolutionary processes (Carson, 1970). The high degree of species endemism from one island to the next suggests that, in Hawaiian Drosophila at least, some sort of founder effect is involved in the events leading to species formation. The building of adaptations, accordingly, is 
relegated to a well-known set of processes involving mutation, recombination and selection within reasonably large mendelian populations.

Since the founder effect is merely an extreme form of allopatric differentiation, it is clear that the Hawaiian data have forced a strongly allopatric view of speciation, although occasional sympatric schemes have been suggested (Craddock, 1974; Richardson, 1974). Most particularly, the sequential differentiation of silvestris populations seems best explained by allopatry. The differentiation involves primarily the premating behavioural system and its associated morphological embellishments rather than adaptation to temperature, humidity, food, host plants, associated species or other facets of the ambient environment. The inversion system turns out to be relatively ancient and conservative and related more to adaptive properties than to speciation.

It has been customary to think of the premating system as being especially sensitive to selective challenges through mating competition from closely related species. The system is theorized to function as a protector which keeps the gene pool from erosion by hybridization with foreign individuals which might produce discordant hybrids or recombinants.

Paterson (1978, 1981), on the other hand, has stressed the point that the premating system can come, over time, to be sharpened into what he calls the "specific-mate recognition system". He views the behavioural interaction of male and female of a species as a primary attribute which is selected for its own intrinsic worth; it can be quite independent of challenges to its integrity from related sympatric species. He conceives of it as ultimately becoming a rather rigid set of characteristics. Any isolating effect that the system may have is viewed as a secondary effect, not the proximate cause of the behaviour observed.

In this view, premating sexual behavior is de-emphasized as a "device" serving to prevent the breakdown of a gene pool and calls into question the prevailing "conventional wisdom" of what Paterson has called the "Isolation Concept" of the species wherein isolation is supposed to be strengthened by selection against hybrids.

One does not have to adopt the details of Paterson's view to realize that concentration on the premating sexual system has considerable merit in interpreting the case of Drosophila silvestris and its relatives. Paterson's formulation relates to sexual signalling systems he considers to have become genetically fixed. Where evidence for strong sexual selection exists, as in $D$. silvestris, the signalling system may be genetically labile and variable. Thus, if a premating system of a youthful species or population is subject to genetic variability wherein epigamic selection by females impinges on a genetically variable field of males, the premating system could acquire a dynamic property capable of substantial shifts. This is especially true if the basis of the variability is polygenic and under stabilizing selection (see Lande, 1981).

Granted these points, it is not difficult to visualize the results of a founder event on a youthful highly labile sexual selection system. Perturbation of the old system by gametic disequilibrium and random drift of gene frequencies could force selection to shift by chance away from an older norm. Stabilising sexual selection would then reestablish a new equilibrium.

It should be stressed that such events could easily occur in allopatry as colonizations occur. It is also possible; as suggested by Arita and Kaneshiro 
(1979) that extreme attenuation of a population in situ could permit such a shift to occur. Expansion of population size again could bring two different mating systems into contact. The isolation which might be observed under these circumstances could be the outcome of the separate readjustments of the mating systems within the relevant populations.

All of these events could occur without the presence of postmating incompatibilities. If each separate premating sexual system is monitored by selection so as to be continually improved, any hybrids between two such systems would find themselves outside the sexual system of either population. The result would mean a sharpening of one or both of the mating systems without recourse to reinforcement by postmating breakdown.

Certain authors who have a macroevolutionary perspective (e.g., Gould, 1980) have developed the concept that species tend to reach an equilibrated state in which progressive evolutionary change is virtually non-existent. This notion of equilibrium from the evolutionary point of view may have some utility in microevolutionary thinking as well. In a rather speculative account, the writer (Carson, 1982) has suggested that the populations of many species may tend towards a balanced obligatory genetic equilibrium which has the effect of dampening down the rate of evolutionary change in its populations. According to this notion, the older a species, the more likely it is to become caught up in these obligatory balances or "closed" variability systems (see also Carson, 1975).

Such equilibrium conditions appear to be most characteristic of many phylogenetically old species from the continents and oceans. On the contrary, study of genetic systems of new terrestrial insular organisms suggests, as Darwin noted in Galapagos, that such organisms are extraordinarily mobile and dynamic from the evolutionary point of view. Insular organisms, especially the very newest ones, may thus still be sufficiently young so that they are not yet caught up in equilibria which have slowed down their ability to change. The organisms of the newest parts of very new volcanic islands indeed appear to be in a somewhat unstable state. Deciphering the nature of this disequilibrium and determining its consequences on islands may bring us closer to understanding what Darwin called "-that mystery of mysteries-the first appearance of new beings on this earth".

Acknowledgments.-The work of the author has been supported by NSF Grant DEB 79266292.

\section{REFERENCES}

AHEARN. J. N. $1980 a$. Evolution of behavioral isolation in a laboratory stock of Drosophila silvestris. Experientia, 36, 63-64.

AHEARN. J. N. 1980b. Loss of behavioral barrier to gene exchange in interspecific hybrids. Genetics, 94, s1.

AHEARN, J. N., CARSON, H. L., DOBZHANSKY, TH., AND KANESHIRO. K. Y. 1974. Ethological isolation among three species of the planitibia subgroup of Hawaiian Drosophila. Proc. Nat. Acad. Sci. USA, 71, 901-903.

ARITA, L. H., AND KANESHIRO, K. Y. 1979. Ethological isolation between two stocks of Drosophila adiastola Hardy. Proc. Haw. Ent. Soc., 13, 31-34.

BRYANT, P. J., AND CARSON. H. L. 1979. Genetics of an interspecific difference in a secondary sexual character in Hawaiian Drosophila. Genetics, $91, \mathrm{~s} 15$. 
CARSON, H. L. 1970. Chromosome tracers of the origin of species. Science, 168, 1414-1418.

CARSON, H. L. 1973. Ancient chromosomal polymorphism in Hawaiian Drosophila. Nature, 241, 200-202.

CARSON, H. L. 1974. Patterns of speciation in Hawaiian Drosophila inferred from ancient chromosomal polymorphism. In Genetic Mechanisms of Speciation in Insects, ed. M. J. D. White, pp. 81-93. Australia and New Zealand Book Co., Sydney, Aust.

CARSON, H. L. 1975. The genetics of speciation at the diploid level. Amer. Nat., 109, 83-92.

CARSON, H. L. 1978. Speciation and sexual selection in Hawaiian Drosophila. In Ecological Genetics: The Interface, ed. P. F. Brussard, pp. 93-107. Springer-Verlag, New York.

CARSON. H. L. 1982. Speciation as a major reorganization of polygenic balances. In Mechanisms of Speciation, ed. M. J. D. White, Alan R. Liss (in press).

CARSON, H. L., AND BRYANT, P. J. 1979. Genetic variation in Hawaiian Drosophila. VI. Change in a secondary sexual character as evidence of incipient speciation in Drosophila. Proc. Nat. Acad. Sci. USA, 76, 1929-1932.

CARSON, H. L., HARDY, D. E., SPIETH, H. T., AND STONE, W. S. 1970. The evolutionary biology of the Hawaiian Drosophilidae. In Essays in Evolution and Genetics in Honor of Theodosius Dobzhansky. eds. M. K. Hecht and W. C. Steere, pp. 437-543. AppletonCentury-Crofts, New York.

CARSON, H. L., AND JOHNSON, W. E. 1975. Genetic variation in Hawaiian Drosophila. I. Chromosome and allozyme polymorphism in $D$. setosimentum and $D$. ochrobasis from the island of Hawaii. Evolution, 29, 11-23.

CARSON, H. L., AND KANESHIRO, K. Y. 1976. Drosophila of Hawaii: Systematics and ecological genetics. Ann. Rev. Ecol. Systematics, 7, 311-346.

CARSON, H. L., AND TERAMOTO, L. T. 1980. Differences in copulatory success among laboratory males of Drosophila silvestris. Genetics, $94, \mathrm{~s} 14$.

CARSON, H. L., VAL, F. C., SIMON, C. M., AND ARCHIE, J. W. 1982. Morphometric evidence for incipient speciation in Drosophila silvestris from the island of Hawaii. Evolution, 36 (in press).

CARSON, H. L., AND YOON, J. S. 1982. Genetics and evolution of Hawaiian Drosophila. In The Genetics and Biology of Drosophila, vol. 3b, eds. M. Ashburner, H. L. Carson and J. N. Thompson Jr. Academic Press, New York. (in press).

ClAyton, F. E. 1976. Metaphase configurations in Drosophila. A comparison of endemic Hawaiian species and non-endemic species. Arkansas Acad. Sci., 30, 32-35.

CLAYTON, F. E., AND WHEELER, M. R. 1975. A catalog of Drosophila metaphase chromosome configurations. In Handbook of Genetics, vol. 3. ed. R. C. King, pp. 471-512. Plenum Press, New York.

CRADDOCK, E. M. 1974. Reproductive relationships between homosequential species of Hawaiian Drosophila. Evolution, 28, 593-606.

CRADDOCK, E. M., AND JOHNSON, W. E. 1974. Genetic variability in the Kilauea Forest population of Drosophila silvestris. US/IBP Island Ecosystems. IRP Tech. Report No. 45, $1-39$.

CRADDOCK, E. M., AND JOHNSON, W. E. 1979. Genetic variation in Hawaiian Drosophila. V. Chromosomal and allozymic diversity in Drosophila silvestris and its homosequential species. Evolution, 33, 137-155.

DOBZHANSKY, TH. 1976. Organismic and molecular aspects of species formation. In Molecular Evolution. ed. F. J. Ayala, pp. 95-105. Sinauer Assoc., Inc. Sunderland, Mass.

GOULD, S. J. 1980. Is a new and general theory of evolution emerging? Paleobiology, 6 , 119-130.

HUNT, J. A., HALL, T. J., AND BRITTEN, R. J. 1981. Evolutionary distances in Hawaiian Drosophila measured by DNA reassociation. J. Molec. Evol., 17, 361-367.

KANESHIRO, K. Y. 1976. Ethological isolation and phylogeny in the planitibia subgroup of Hawaiian Drosophila. Evolution, 30, 740-745.

KANESHIRO. K. Y. 1980. Sexual isolation, speciation and the direction of evolution. Evolution, $34,437-444$.

KANESHIRO, K. Y., AND KURIHARA, J. S. 1982. Sequential differentiation of sexual behavior in populations of Drosophila silvestris. Pacific Science, 35, 177-183.

KANESHIRO, K. Y., AND VAL, F. C. 1977. Natural hybridization between a sympatric pair of Hawaiian Drosophila. Amer. Nat., 111, 897-902.

LANDE, R. 1981. Models of speciation by sexual selection on polygenic traits. Proc. Nat. Acad. Sci. USA, 78, 3721-3725.

MAYR, E. 1945. Age of the distribution pattern of the gene arrangements in Drosophila pseudoobscura. Lloydia, 8, 69-83. 
MUELLER-DOMBOIS, D., BRIDGES, K. W., AND CARSON, H. L., eds. 1981. Island Ecosystems: Biological Organization in Selected Hawaiian Communities. US/IBP Synthesis Series, vol. 15, p. 583. Hutchinson Ross Publ. Co., Stroudsburg, Pa.

OHTA, A. T. 1978. Ethological isolation and phylogeny in the grimshawi species complex of Hawaiian Drosophila. Evolution, 32, 485-492.

PATERSON. H. E. H. 1978. More evidence against speciation by reinforcement. S. Afr. J. Sci., $74,369-371$.

PATERSON, H. E. H. 1981. The continuing search for the unknown and the unknowable: A critique of contemporary ideas on speciation. S. Afr. J. Sci., 77, 113-119.

POWELL, J. R. 1978. The founder-flush speciation theory: An experimental approach. Evolution, 32, 465-474.

RICHARDSON, R. H. 1974. Effects of dispersal, habitat selection and competition on a speciation pattern of Drosophila endemic to Hawaii. In Genetic Mechanisms of Speciation in Insects. ed. M. J. D. White, pp. 140-164. Australia and New Zealand Book.Co. Sydney, Australia.

SENE, F. M., AND CARSON, H. L. 1977. Genetic variation in Hawaiian Drosophila. IV. Close allozymic similarity between $D$. silvestris and $D$. heteroneura from the island of Hawaii. Genetics, 86, 187-198.

SPIESS, E. B., AND CARSON, H. L. 1981. Evidence for sexual selection in Drosophila silvestris of Hawaii. Proc. Nat. Acad. Sci. USA, 78, 3088-3092.

SPIETH, H. T. 1978. Courtship patterns and evolution of the Drosophila adiastola and planitibia species subgroups. Evolution, 32, 435-451.

TEMPLETON, A. R. 1977. Analysis of head shape between two interfertile species of Hawaiian Drosophila. Evolution, 31, 630-641.

TEMPLETON, A. R. 1980. The theory of speciation via the founder principle. Genetics, 94, 1011-1038.

THROCKMORTON, L. H. 1975. The phylogeny, ecology and geography of Drosophila. In Handbook of Genetics. ed. R. C. King, pp. 431-469. Plenum Press, New York.

VAL, F. C. 1977. Genetic analysis of the morphological differences between two interfertile species of Hawaiian Drosophila. Evolution, 31, 611-629.

WATANABE, T, K., AND KAWANISHI, M. 1979. Mating preference and the direction of evolution in Drosophila. Science, 205, 906-907.

WATSON, G. C. 1979. On premating isolation between two closely related species of Hawaiian Drosophila. Evolution, 33, 771-774.

WATSON, G. C. 1980 . A note on differences in the mating behavior of Drosophila heteroneura and D. silvestris. Experientia, 36, 62-63. 